Relations industrielles

Industrial Relations

\title{
Trade Union Growth in Canada : A Comment
}

\section{George Bain et F. Elsheikh}

Volume 31, numéro 3, 1976

URI : https://id.erudit.org/iderudit/028730ar

DOI : https://doi.org/10.7202/028730ar

Aller au sommaire du numéro

\section{Éditeur(s)}

Département des relations industrielles de l'Université Laval

\section{ISSN}

0034-379X (imprimé)

1703-8138 (numérique)

Découvrir la revue

Citer cet article

Bain, G. \& Elsheikh, F. (1976). Trade Union Growth in Canada : A Comment. Relations industrielles / Industrial Relations, 31(3), 482-490.

https://doi.org/10.7202/028730ar

Tous droits réservés (C) Département des relations industrielles de l'Université Laval, 1976
Ce document est protégé par la loi sur le droit d'auteur. L'utilisation des services d'Érudit (y compris la reproduction) est assujettie à sa politique d'utilisation que vous pouvez consulter en ligne.

https://apropos.erudit.org/fr/usagers/politique-dutilisation/ 


\title{
TRADE UNION GROWTH IN CANADA: A COMMENT
}

\author{
George Sayers Bain \\ and \\ Farouk Elsheikh
}

In a recent paper in this journal, ${ }^{1}$ Swidinsky developed an econometric model of union growth in Canada between 1911 and 1970. The purpose of this note is to evaluate his model and to demonstrate that some of the conclusions which he derives from it need to be revised.

\section{THE SWIDINSKY MODEL}

Swidinsky's basic equation is

$\Delta \mathrm{M}_{\mathrm{t}}=\beta_{0}+\beta_{1} \Delta \mathrm{E}_{\mathrm{t}}+\beta_{2} \Delta \mathrm{S}_{\mathrm{t}}+\beta_{3} \mathrm{U}_{\mathrm{t}}+\beta_{4} \Delta \mathrm{P}_{\mathrm{t}-1}+\beta_{5} \mathrm{~T}_{\mathrm{t}-1}+\beta_{6} \Delta \mathrm{M}^{*}{ }_{\mathrm{t}}+\epsilon_{\mathrm{t}}$ where $\Delta \mathrm{M}_{\mathrm{t}}$ is the rate of change of union membership, $\Delta \mathrm{E}_{\mathrm{t}}$ is the rate of change of employment in unionised firms. $\Delta t_{t} t$ is the rate of change in the number of strikes, $U_{t}$ is the level of unemployment, $\Delta P_{t-1}$ is the rate of change of prices lagged one year, $T_{t-1}$ is the level of trade union membership as a percentage of non-agricultural paid workers lagged one year, $\Delta \mathbf{M}^{*} \mathrm{t}$ is the rate of change of American union membership, $\epsilon$ is a random disturbance term, and the expected signs of all the coefficients are positive except those of $\beta_{3}$ and $\beta_{5}$.

Although $\Delta \mathrm{E}_{\mathrm{t}}$ is expected to exert a positive influence on union growth, 'the magnitude of this influence depends on the distribution of employment changes among firms with different degrees of unionization and the prevalence of union security arrangements'. $\Delta S_{t}$ is regarded as a proxy for changes in union recruiting activity. $U$ is expected to have a negative impact upon union growth, partly because 'the costs of union membership loom larger relative to the benefits' in a period of growing unemployment and partly because 'unions are urlikely to undertake costly organizing campaigns in the face of declining revenues caused by unemployment among their membership' and 'when the probability of success is low'. $\Delta \mathrm{P}_{\mathrm{t}-1}$ is included in the model 'to test the argument set forth by Ashenfelter and Pencavel that unions are partly defensive organizations in that workers accept unionization in

* G. S. BAIN, Director of the SSRC Industrial Relations Research Unit, University of Warwick, England.

** F. ELSKEIKH, Associate Professor of Econometrics, Kuwait University, and formerly of the University of Warwick, England.

1 R. SWIDINSKY, “Trade Union Growth in Canada: 1911-1970", Relations Industrielles, XXIX, no. 3 (1974), 435-51. 
inflationary periods as a means of protecting their real wages'. ${ }^{2} T_{t-1}$ is used to test 'the hypothesis that as union membership increases the recruitment of additional membership becomes more difficult'. Finally, $\Delta \mathrm{M}^{*} \mathrm{t}$ is included in the model because

\begin{abstract}
the close relation between U.S. and Canadian trade unions through the international union suggests that the rate of growth of unions in the U.S. may also be an important explanatory variable. Conceivably, a major organizing thrust in the U.S. may spill over into Canada, partly as a consequence of the international corporate structure. There is also the possibility that Canadian workers may react strongly to events and trends in the U.S., especially to changes in labour legislation. ${ }^{3}$
\end{abstract}

The above model was fitted by means of the ordinary least squares technique to annual data for the period 1911-70 and for two sub-periods, 1911-39 and 1946-70. The results are given by Regressions 1, 2, and 3 in Table 1. As can be seen from Regression 1, the estimated equation for 1911-70 tends to support the arguments advanced by Swidinsky. The independent variables account for approximately 72 per cent of the variance in union growth. All the regression coefficients have the expected signs and, with the exception of $\Delta \mathrm{E}_{\mathrm{t}}$ and $\Delta_{\mathrm{t}-1}$, are significantly different from zero. In contrast, the estimated equation for 1911-39 (Regression 2) is 'rather poor': the coefficient of $U_{t}$ obtains the wrong sign and those of all but two of the independent variables, $\mathrm{T}_{\mathrm{t}-1}$ and $\Delta \mathrm{M}_{\mathrm{t}}$, are insignificant. The estimated equation for 1946-70 (Regression 3 ) is slightly better, but even here the coefficients of $\Delta \mathbf{M}^{*}{ }_{t}$ and $\Delta S_{t}$ are insignificant and that of $\Delta \mathrm{P}_{\mathrm{t}-1}$ is not only insignificant but also has the wrong sign.

Swidinsky concludes from these results that the consistent insignificance, and even unexpected sign of the $\Delta \mathrm{P}_{t}$ coefficient is a strong contradiction of the thesis that unions are partly defensive organizations'. He claims that "this finding is not altered if different lag specifications on $\Delta \mathrm{P}$ are introduced' or if 'changes in real wages are used instead of price changes'. He also implies that the differences between the estimated equations for 1911-39 and for 1946-70 support his argument that 'the factors related to union growth prior to 1939, when unions were struggling for recognition, are quite different from those in the latter period when unions become well entrenched'.

2 Orley ASHENFELTER and John H. PENCAVEL, "American Trade Union Growth: 1900-1960," Quarterly Journal of Economics, LXXXIII (August 1969), 434-48.

3 Unless otherwise indicated, all the quotations in this paper are from SWIDINSKY, op. cit. 


\section{TABLE 1}

Swidinsky's determinants of the rate of change of union membership in Canada, 1911-1970 and 1921-1969

REGRESSION 1

2 3 4 5

6

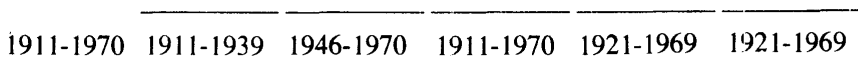

Summary

Statistics

$\begin{array}{lcccrrr}\mathrm{R}^{2} & 0.72 & 0.78 & 0.89 & 0.7282 & 0.7640 & 0.5529 \\ \text { SEE } & \text { n.a. } & \text { n.a. } & \text { n.a. } & 4.7120 & 3.0340 & 4.5720 \\ \text { F } & \text { n.a. } & \text { n.a. } & \text { n.a. } & 22.7716 & 21.5806 & 8.2434 \\ \text { DW } & 1.56 & 1.73 & 1.34 & 1.7420 & 1.3657 & 2.1648\end{array}$

Estimated

Coefficients

Constant

11.16

26.23

26.42

9.8116

9.4609

9.1106

$\Delta \mathrm{E}_{\mathrm{t}}$

(3.83)

(3.01)

(5.56)

(3.9494)

(4.1036)

(2.5241)

0.22

0.18

0.37

0.1835

0.2599

0.2566

(1.58)

$(0.67)$

(2.28)

(1.3390)

(2.5175)

(1.9843)

$\Delta \mathrm{P}_{\mathrm{t}-1}$

0.28

0.60

$-0.24$

0.3262

0.3455

0.3088

$\Delta S_{\mathrm{t}}$

(1.38)

(1.67)

$(-1.66)$

(1.6626)

(1.6704)

(1.3350)

0.12

0.02

0.01

0.1302

0.0960

0.0441

$\mathrm{U}_{\mathrm{t}}$

(4.28)

(0.27)

(0.07)

(5.2768)

(3.8744)

(1.8693)

$-0.81$

0.16

$-1.05$

$-0.6879$

$-0.5921$

$-0.4981$

$(-3.43)$

(0.30)

$(-3.12)$

$(-3.3356)$

$(-3.7051)$

$(-2.1736)$

$T_{t-1}$

$-0.18$

$-1.91$

$-0.67$

$-0.1544$

$-0.1511$

$-0.1380$

$\Delta \mathrm{M}^{{ }^{*}}$

$(-2.06)$

$(-2.45)$

$(-4.07)$

(-2.0382)

$(-2.0700)$

$(-1.2668)$

0.28

0.26

0.55

0.2886

0.2432

0.1810

(3.11)

(1.96)

(1.51)

(3.0483)

(3.7615)

(2.0061)

NOTES: Figures in parenthesis are estimated t-values.

SEE is the standard error of the estimated regression.

DW is the Durbin-Watson statistic, a measure of the first order serial correlation in the estimated residuals.

The rates of change in Regressions 1-5 are defined as central differences, $\Delta \mathrm{X}_{\mathrm{t}}=\left(\mathrm{X}_{\mathrm{t}+1}-\mathrm{X}_{\mathrm{t}-1}\right) / 2 \mathrm{X}_{\mathrm{t}}$. Those in Regression 6 are defined as $\Delta \mathrm{X}_{\mathrm{t}}=\left(\mathrm{X}_{\mathrm{t}}-\mathrm{X}_{\mathrm{i}-1}\right) / \mathrm{X}_{\mathrm{t}}$

n.a. figures not available

\section{AN EVALUATION OF THE MODEL}

Swidinsky's model ${ }^{4}$ and the conclusions which he derives from it can be challenged on theoretical, statistical, and methodological

${ }_{4}$ The authors are grateful to Professor Swidinsky for facilitating this evaluation by providing them with his data. 
grounds. To take the theoretical objections first, $\Delta E_{t}$ captures not one but three effects, as has been shown elsewhere, and some of these can be more appropriately measured by other variables. ${ }^{5}$ Although $\Delta \mathrm{S}_{\mathrm{t}}$ is correlated with $\Delta \mathrm{M}_{\mathrm{t}}$, it is doubtful if the relationship holds because $\Delta \mathrm{S}_{\mathrm{t}}$ is a 'proxy for changes in union recruiting activity'. A more plausible reason why $\Delta \mathrm{S}_{\mathrm{t}}$ and $\Delta \mathrm{M}_{\mathrm{t}}$ move together is that they have a common cause: the rate of change of prices. Walsh has shown that price inflation is the 'key determinant' of the rate of change in the number of strikes in Canada. ${ }^{6}$ And this note demonstrates below that price rises are also an important determinant of Canadian union growth. In short, $\Delta \mathrm{S}_{\mathrm{t}}$ and $\Delta \mathrm{M}_{\mathrm{t}}$ probably have no significant connection with each other except through their separate relationships to $\Delta \mathrm{P}_{\mathrm{t}}$.

Swidinsky's model is also weakened by the data upon which it is based. It uses American union membership data developed by Bernstein. These data have been severely criticised by Troy, and his criticisms are borne out by the more accurate data of both the Bureau of Labor Statistics and the National Bureau of Economic Research which have become available since Bernstein's work was published. ${ }^{7}$ No reliable unemployment data exist for Canada prior to 1921. Swidinsky extends his unemployment series back to 1911, however, by using the unemployment rate among trade unionists for 1915-20 and the American unemployment rate for 1911-14. Given the weaknesses of these data, he would have been better advised to begin estimating his model in 1921.

Even if Swidinsky's model were free of these theoretical and statistical weaknesses, it would still be characterised by two major methodological shortcomings. One of these concerns the way the variables are defined, and the other the way in which the model is specified.

Swidinsky defines all of the rate-of-change variables in his model by means of the central differences method (i.e. $\left.\Delta X_{t}=\left(X_{t+1}-X_{t-1}\right) / 2 S_{t}\right)$ This method smoothes the series and generally gives misleadingly high coefficients of determination $\left(\mathrm{R}^{2}\right)$. It also affects the Durbin-Watson statistic as well as the estimated standard errors of the coefficients and hence the t-values. ${ }^{8}$ This point is illustrated by Regressions 5 and 6 in Table 1.9 The rates of change are defined as central differences in

5 G. S. BAIN and Farouk EESHEIKH, Union Growth and the Business Cycle: An Econometric Analysis (Oxford: Blackwell, 1976), 38-39.

6 William D. WALSH, "Economic Conditions and Strike Activity in Canada," Industrial Relations, XIV (February 1975), 45-54.

7 See BAIN and ELSHEIKH, op. cit., 15 on this point.

8 For a brief discussion of the central differences method see R. G. LIPSEY, "The Relation Between Unemployment and the Rate of Change of Money Wage Rates in the United Kingdom 1862-1957: A Further Analysis,' Economica, XXVII (February 1960), $2-3$.

9 Regression 4 is given so that it can be compared with Regression 1. As can be seen, it proved impossible to replicate Swidinsky's reported results. 
Regression 5 and as $X_{t}=\left(X_{t}-X_{t-1}\right) / X_{t}$ in Regression 6.10 Although the magnitudes of the estimated coefficients are similar in these two regressions, the summary statistics and the t-values are higher in Regression 5 than in Regression 6, some coefficients which are significant in Regression 5 are insignificant in Regression 6, and autocorrelation is present in Regression 5 but not in Regression 6. ${ }^{11}$ Clearly. Swidinsky's results are affected by his use of the central differences method, and his conclusions must be treated with caution.

The shortcomings in the way Swidinsky specified his model were discovered by re-running it using different combinations of the explanatory variables and analysing the contribution which each of these makes. This analysis revealed that the lagged density variable $\left(T_{t-1}\right)$, whether on its own or in combination with other variables, did not significantly improve the fit. ${ }^{12}$ It appears with a significant coefficient only when used with all the other variables, and its significance comes at the expense of $\Delta \mathrm{E}_{\mathrm{t}}$ and $\Delta \mathrm{P}_{\mathrm{t}-1}$ whose coefficients are drastically reduced in magintude and become insignificant. ${ }^{13}$ These findings suggest that in Canada, unlike certain other countries, the lagged level of union density is not an important determinant of union growth. ${ }^{14}$

The re-run of Swidinsky's model also indicated that the introduction of $\Delta \mathrm{S}_{\mathrm{t}}$ and/or $\mathrm{U}_{\mathrm{t}}$ affects the magnitudes and/or the significance of $\Delta \mathrm{M}^{*}, \Delta \mathrm{E}_{\mathrm{t}}$, and $\Delta \mathrm{P}_{\mathrm{t}-1}$. The instability of these variables, together with that of $\mathrm{T}_{\mathrm{t}-1}$, suggests that Swidinsky's model may be seriously affected by multicollinearity. The existence of multicollinearity does not bias the estimates, but it does make them imprecise, and this imprecision means that no firm conclusions can be drawn about their size or significance. ${ }^{15}$

11) An alternative definition was also where $X_{t}$ is defined as $\log X_{t}-\log X_{t-1}$, and the results were almost identical with those given in Regression 6.

11 Strictly speaking, the existence of autocorrelation invalidates the significance tests. Nevertheless, if the significance test is applied, the estimated standard errors are underestimated and thus the $t$-values are overestimated. The autocorrelated residuals may result from the use of the central differences method.

12 This conclusion held however the rate-of-change variables were defined. The improvement in fit was assessed by using the appropriate F-test. See BAIN and ELSHEIKH, op. cit., Appendix B for details of this test.

13 The coefficient of $\Delta \mathrm{E}_{\mathrm{t}}$ is almost halved and that of $\Delta \mathrm{P}_{\mathrm{t}-1}$ more than halved when $\mathrm{T}_{\mathrm{t}-1}$ is introduced.

14 On this point see Bain and Elsheikh, op. cit., 105-14.

15 The correlation coefficients between, for example, $\mathrm{U}_{\mathrm{t}}$ and $\Delta \mathrm{P}_{\mathrm{t}-1}$, and $\Delta \mathrm{P}_{\mathrm{t}-1}$ and $T_{t-1}$ are -0.67 and 0.48 respectively. These correlation coefficients may not appear particularly high. But as J. KMENTA, Elements of Econometrics (London: Macmillan, 1971), 383-4 has pointed out, 'when there are more than two explanatory variables, we cannot simply look at the coefficients of correlation and conclude that the sample is not perfectly (or highly) multicollinear'. For, as he has shown, perfect multicollinearity can exist in the case of three regressors where none of the correlation coefficients is greater than 0.5 in absolute value. 
Since multicollinearity becomes more serious the smaller the sample size, Swidinsky's sub-period analysis is particularly unreliable, ${ }^{16}$ and hence no firm conclusions can be drawn about the importance of particular variables during the sub-periods 1911-39 and 1946-70. Nor is it possible to imply from the differences between the estimated equations for these two periods that 'the factors related to union growth prior to 1939, when unions were struggling for recognition, are quite different from those in the latter period when unions become well entrenched'. Such a conclusion would only be valid if a Chow test had been applied and indicated that a structural break had occurred around 1939. ${ }^{17}$

\section{AN ALTERNATIVE VIEW}

An alternative view of the determinants of Canadian union growth can be obtained by constructing a simplified model which contains a subset of the variables used by Swidinsky. This model employs only three variables: the current rate of change of American union membership $\left(\Delta \mathrm{M}^{*} t\right)$, the current rate of change of prices $\left(\Delta \mathrm{P}_{t}\right)$, and the level of unemployment $\left(\mathrm{U}_{\mathfrak{t}}\right)$. The results of this model are given in Table 2 . The rates of change in Regressions 1-3 are defined as central differences; Regressions 4-6 use the alternative and preferred definition of the rate of change, $\Delta X_{t}\left(X_{t}-X_{t-1}\right) / X_{t}$.

A comparison of Regression 1 in Table 2 with Regression 5 in Table 1 demonstrates that although the simplified model uses fewer explanatory variables than that developed by Swidinsky, it performs as well in terms of $\mathrm{R}^{2}$ and better in terms of Durbin-Watson statistic when the rates of change are defined as central differences. The only insignificant variable is $\Delta \mathrm{F}_{\mathrm{t}}$ which is also insignificant in Swidinsky's model. But when the preferred definition of the rate of change is used, as in Regression 4 of Table 2, all the estimated regression coefficients, including that of $\Delta \mathrm{F}_{t}$, are significant, possess the correct signs, and have reasonable magnitudes. The satisfactory nature of the model is also demonstrated by the summary statistics of Regression 4 .

The simplified model was then estimated for the two sub-periods, 1921-45 and 1946-69. An examination of Regressions 5 and 6 in Table 2 indicates that $\Delta \mathrm{P}_{t}$ is not significant in either sub-period and that $\mathrm{U}_{t_{t}}$ loses its significance in the earlier period. The insignificance of these regressors can be explained by the existence of multicollinearity which is aggravated by the small size of the samples. In order to test the structural stability of the model over both sub-periods, a Chow test was applied, and it indicated that the magnitudes of the 1921-45 set

16 Note, for example, the unreasonable magnitudes of some of the significant coefficients in the sub-period analysis: 1.05 for $U_{t}$ in the postwar period and -1.91 and -0.67 for $T_{t-1}$, not to mention the size of the constant term.

17 See G. C. CHOW, "Tests of Equality Between Sets of Coefficients in Two Linear Regressions," Econometrica, XXVIII (1960), 591-605, and BAIN and ELSHEIKH, $o p$. cit., Appendix B for details of this test. 
TABLE 2

The determinants of Canadian union growth, 1921-1969

\section{REGRESSION}

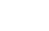

$1921-1969$

2

1921-1945

3

1946-1969

4

$1921-1969$
5

$1921-1945 \quad 1946-1969$

Summary

Statistics

$\begin{array}{lrrrrrr}\mathrm{R}^{2} & 0.7592 & 0.7619 & 0.7424 & 0.6074 & 0.6183 & 0.5995 \\ \mathrm{SEE} & 2.6396 & 3.5956 & 1.4558 & 3.9139 & 5.2833 & 2.1553 \\ \mathrm{~F} & 45.1877 & 21.3383 & 18.2481 & 22.6944 & 10.8008 & 9.9787 \\ \text { DW } & 1.5379 & 1.6024 & 1.2525 & 2.1309 & 1.9193 & 1.4421\end{array}$

Estimated

Coefficients

Constant

$$
5.5854
$$

5.6627

5.6137

4.5100

4.4458

7.7343

(6.7689)

(4.4289)

(3.9064)

(3.8861)

(2.3799)

(3.5609)

$\Delta \mathrm{M}^{*}{ }_{t}$

0.5888

0.5996

0.5221

0.4358

0.3744

0.3421

$\Delta \mathrm{P}_{\mathrm{t}}$

(8.1116)

(4.1884)

(3.6435)

(4.9336)

(2.4313)

(2.1122)

0.1510

0.1204

0.1994

0.3622

0.5872

0,1217

$\mathrm{U}_{\mathrm{t}}$

(1.0134)

(0.3193)

(1.4236)

(1.9682)

(1.4681)

(0.7025)

$-0.5596$

$-0.5721$

$-0.5873$

$-0.3785$

$-0.3081$

$-0.9475$

$(-4.7801) \quad(-3.0961)$

$(-2.2912)$

$(-2.3756)$

$(-1.3086)$

$(-2.3675)$

NOTES: Figures in parentheses are estimated t-values.

SEE is the standard error of the estimated regression

DW is the Durbin-Watson statistic, a measure of the first order serial correlation in the estimated residuals.

Rates of change are defined as $\Delta \mathrm{X}_{\mathrm{t}}=\left(\mathrm{X}_{\mathrm{t}+1}-\mathrm{X}_{\mathrm{t}-1}\right) / 2 \mathrm{X}_{\mathrm{t}}$ in

Regressions $1-3$ and as $\Delta X_{t}=\left(X_{t}-X_{t-1}\right) / X_{t}$ in Regressions 4-6.

of estimated regression coefficients are not significantly different from those of the 1946-69 set of coefficients. In other words, the model is stable over time.

Finally, in order to test the predictive ability of the simplified model, Regressions 5 and 6 were used to generate predictions outside the sample periods. In other words, predictions were obtained for 194669 by using Regression 5 for 1921-45, and for 1945-1922 by using Regression 6 for 1946-69. The quality of these predictions was then measured by calculating the Theil inequality coefficient and its three components: the bias, variance, and covariance proportions. ${ }^{18}$ The results are given in Table 3.

is The closer the inequality coefficient is to zero the better the predictions. The coefficient can be decomposed into three inequality components known as the bias, variance, and covariance proportions. If the bias and variance proportions make up a large part of the inequality coefficient, the investigator can improve the quality of the predictions by respecifying the model. See H. THEIL, Applied Economic Forecasting (Amsterdam: North Holland, 1966), 26-32: and idem, Economic Forecasts and Policy (second edition: Amsterdam: North-Holland, 1961), 32. 
Table 3 indicates that the model's predictive ability is satisfactory.

TABLE 3

The Theil inequality coefficient

Prediction Criteria

Theil Inequality Coefficient

Bias Proportion

Variance Proportion

Covariance Proportion
Predictions For 1946-1969

0.2144

0.1528

0.0148

0.8324
Predictions For 1945-1922

0.4037

0.0458

0.0554

0.8988

The overall coefficient is quite low, and most of the prediction errors stem from the covariance proportion. Forecasters can do nothing to eliminate errors arising from this source, and hence no significant improvement could be obtained by respecifying the model. In short, the model predicts as well as can be reasonably expected. ${ }^{19}$

\section{CONCLUSION}

This note has advanced a number of criticisms of the econometric model developed by Swidinsky to explain Canadian union growth. In particular, it has suggested that the statistical weaknesses which characterise his model severely limit the confidence which can be placed in the results it produces.

An alternative model of Canadian union growth was therefore developed. It is a simplified model which employs only three explanatory variables: the rate of change of prices, the level of unemployment, and the rate of change of American union membership. Nevertheless, the model is clearly satisfactory when judged in terms of the usual criterion of overall goodness of fit as well as in terms of the signs, magnitudes, and significance of the estimated regression coefficients. It is also satisfactory when judged in terms of its structural stability and predictive ability. And it suggests, in contrast to Swidinsky's findings, that the rate of change of prices is an important determinant of union growth, that the rate of change of American union membership continued to have an impact upon Canadian union growth after 1945, and that, in general, the pre-war and post-war determinants of Canadian union growth are similar.

19 By comparison, Swidinsky's model performs less well. Using Regression 5 of Table 1 to predict the period 1946-69 results in a Theil inequality coefficient of 0.4076 , a bias proportion of 0.8182 , a variance proportion of 0.0044 , and a covariance proportion of 0.1774 . Using the same regression to predict the period 1945-1922 results in a Theil inequality coefficient of 0.4807 , a bias proportion of 0.8197 , a variance proportion of 0.0109 , and a covariance proportion of 0.1694 . It is worth noting that in both cases the bias proportion in the simplified model is very small while that in Swidinsky's model is about 82 per cent (see footnote 18). 


\section{DATA SOURCES}

UNION MEMBERSHIP

Both the Canadian and American union membership data are from G. S. BAIN and R. J. PRICE, Profiles of Union Growth: A Statistical Portrait of Eight Countries (Oxford: Blackwell, forthcoming).

\section{UNEMPLOYMENT}

Unemployment data for 1921-45 are from M. C. URQUHART and K. A. H. BUCKLEY, Historical Statistics of Canada (Toronto: Macmillan, 1965), p. 61 series 54; those for 1946-69 are from The Labour Force (Ottawa: Statistics Canada, Catalogue No. 71001, July 1973), table 33.

PRICES

Price data are from URQUHART and BUCKLEY op. cit., p. 304, series J139152 and from various issues of the Labour Gazette which is published monthly by the Canada Department of Labour.

\section{LA POLITISATION DES RELATIONS DU TRAVAIL (28ème congrès 1973)}

Introduction, Gilles LAFlamme - Les formes historiques de politisation du syndicalisme au Québec, LÉo RoBack - L'évolution socio-économique et le déplacement des centres de pouvoir, BERNARd Solasse - L'impact des secteurs public et para-public sur la politisation des relations du travail, JEAN BoIviN - La philosophie du Code du travail, Jean-Réal Cardin - Les limites du négociable et le débordement des conflits, André Thibaudeau - Positions des partis politiques devant la politisation des relations du travail, ROBERT Burns, André Déom, Michel Bellavance - Conséquences de la politisation des relations du travail, Gérard Dion - Annexe : Négociation collective dans un monde en évolution.

1 volume, 170 pages - Prix : $\$ 5.50$

LES PRESSES DE L'UNIVERSITE LAVAL

CITÉ UNIVERSITAIRE

Québec, P.Q., CANADA

G1K 7R4 